\title{
PHYSICOCHEMICAL, PHYTOCHEMICAL AND CHROMATOGRAPHIC INVESTIGATION OF NEEM (AZADIRACHTA INDICA) SEED OIL
}

\author{
Mayuri Kale*, Shraddha Dhanokar, Anilkumar Aher and Sonali Gawali \\ MVP's college of pharmacy, Nasik, Maharashtra, India.
}

\begin{abstract}
The Azadirachta indica (Neem) plant is a very common folklore medicine used since ancient times for the treatment of various diseases. Neem plant is mainly known for its antimicrobial and insecticidal activities. The pharmacological actions of neem are due to different chemical constituents present in different parts of the plant. Neem plant is a rich source of different compounds like nimbin, nimbidin, quercetin and azadirachtin which are responsible for its pharmacological actions. Most chemical constituents of neem are present in leaves and seeds of the plant. Neem leaves are mainly used in many dentifrices and cosmetics for their antimicrobial activity and neem seed oil is mainly used in insecticidal preparations due to its potent insecticidal activity. This study comprises of physicochemical, phytochemical and chromatographic evaluation of neem seed oil.
\end{abstract}

Keywords: Azadirachta indica, Neem oil, Phytochemical evaluation and TLC.

\section{INTRODUCTION}

Traditional medicines are gaining popularity in this era where the patients are more concerned about side effects of any mediation. In Ayurvedic system of medicines plants are used as the source of most medicines. Each plant has specific Pharmacological activity based on the active principals present in that plant. Plants consist of number of different chemical constituents which gives the pharmacological action. While studying any plant drug the Phytochemistry of the drug should be studied to gain knowledge about the class of chemical compounds present in that plant.

TheAzadirachta indica A. Juss plant belonging to Mahogamyfamily Meliaceae is a subtropical plant indigenous to indo pak subcontinent. Neem plant is used in various traditional medicines in Ayurverdic system of medicines for its different pharmacological activities like Antiviral, Antimicrobial, Antiulcer and Antibacterial. The pharmacological activities of neem plant are mainly due to presence of different terpenoids in different parts of the plant. The concentration of terpenoids in neem plant varies from $0.3-0.8 \%$ in different plant parts. Seeds of neem plant consist of relatively high concentrations of terpenoids than other parts of the plant.

Neem oil is mainly isolated from neem seeds and is used for different purposes like in cosmetics, insecticides, pesticides, Antibacterial and Antiviral. Neem oil consists of a triterpenoid Azadirachtin which is a potent antimicrobial compound. Azadirachtin acts by inhibiting the formation of microtubules. Due to presence of various limonoids and triterpenoids, neem oil is commonly used in various insect repellant formulations and pesticides.

\section{MATERIALS AND METHODS Collection}

Neem seed oil was procured from local market of Nashik area

\section{Sample preparation}

Sample was prepared by dissolving neem oil in methanol and then it was used for physicochemical and phytochemical evaluation. 


\section{Physico chemical evaluation of neem seed oil}

Different Physicochemical parameters such as Viscosity, Relative density, Specific gravity, Refractive index, lodine value, Saponification value and Acid valuewere studied for neem seed oil.

\section{Phytochemical evaluation}

The Neem oil dissolved in methanol was used for phytochemical evaluation; tests for different classes of chemical constituents were performed.

\section{Chromatographic evaluation}

Thin Layer chromatography was performed for neem oil the sample for TLC was prepared by dissolving oil in methanol. The mobile phase used for TLC was Chloroform: Acetone (8:2). Spot for Azadirachtin (Triterpenoid) was obtained at Rf 0.36 , Visualized under $366 \mathrm{~nm}$.

\section{RESULT AND DISCUSSION}

The Physicochemical evaluation of neem seed oil indicated that the oil is greenish brown in colour with unpleasant odour and very bitter test. Neem seed oil is found to be soluble in polar organic solvents methanol, ethanol and ethyl acetate. The other physicochemical parameters such as viscosity, relative density, specific gravity, refractive index, iodine value, acid value and saponification value define physicochemical nature of the oil (Table no.1). The Phytochemical investigation of oil shows the presence of terpenoids, phenolic compounds, saponins, tannins and flavonoids (Table no. 2). Chromatographic investigation confirmed the presence of triterpenoid Azadirachtin in the oil (Table no 3).

\section{CONCLUSION}

Physicochemical, Phytochemical and Chromatographic investigation of Neem seed oil was performed. The results indicate that the neem seed oil consists of variability of chemical constituents. The Thin Layer Chromatography of neem seed oil indicates the presence of triterpenoid Azadirachtin at Rf 0.36 . This investigation is helpful in determining the nature of Phytoconstituents present in neem seed oil.

Table 1: Physico chemical evaluation of neem oil

\begin{tabular}{|c|c|c|}
\hline S. No. & Parameters & Observations \\
\hline 1. & Color & Greenish brown \\
\hline 2. & Odour & Unpleasant, Characteristic \\
\hline 3. & Taste & Bitter \\
\hline 4. & Solubility & $\begin{array}{c}\text { Soluble in methanol, ethanol } \\
\text { and Ethyl acetate }\end{array}$ \\
\hline 5. & Viscosity & 7 centistoke \\
\hline 6. & Relative density & $0.88 \mathrm{~g} / \mathrm{cm} 3$ \\
\hline 7. & Specific gravity & 0.928 \\
\hline 8. & Refractive index & 1.4638 \\
\hline 9. & lodine Value & 70 \\
\hline 10. & Saponification Value & 190 \\
\hline 11. & Acid Value & 40 \\
\hline
\end{tabular}

Table 2: Phytochemical Evaluation

\begin{tabular}{|c|c|c|c|c|}
\hline Sr. No. & Class of Compounds & Tests & Observation & Result \\
\hline \multirow{2}{*}{1.} & Carbohydrates & Molisch's test & Violet ring at junction of two liquids & Negative \\
\cline { 3 - 5 } & Alkaloids & Felhings test & Brick red precipitate & Negative \\
\hline 2. & & Mayer's test & Precipitate & Negative \\
\hline & & Wagner's test & Reddish brown precipitate & Negative \\
\hline 3. & Glycosides & Borntragers test & Pink color to the ammonical layer & Negative \\
\hline \multirow{3}{*}{4.} & \multirow{2}{*}{ Terpenoids } & Salkowski test & $\begin{array}{c}\text { Chloroform layer appears red and } \\
\text { acid layer gives greenish yellow } \\
\text { fluorescence }\end{array}$ & Positive \\
\cline { 3 - 5 } & & Libermann's reaction & Blue color & Positive \\
\hline 5. & Flavonoids & Shinoda test & Orange, pink, red to purple color & positive \\
\hline 6. & \multirow{2}{*}{ Phenolic compounds } & Ferric chloride test & Dark green color & positive \\
\cline { 3 - 5 } & Lead acetate test & Bulky white precipitate & positive \\
\hline 7. & Saponins & Frothing test & Foam lasting for 1 min & positive \\
\hline 8. & Tannins & Gelatin test & White precipitate & positive \\
\hline
\end{tabular}

Table 3: Chromatographic evaluation of neem seed oil

\begin{tabular}{|c|c|c|c|}
\hline Sample & Mobile phase & Visualization & Rf value \\
\hline Neem seed oil in methanol(Azadirachtin) & Chloroform: Acetone (8:2) & UV (366nm) & 0.36 \\
\hline
\end{tabular}




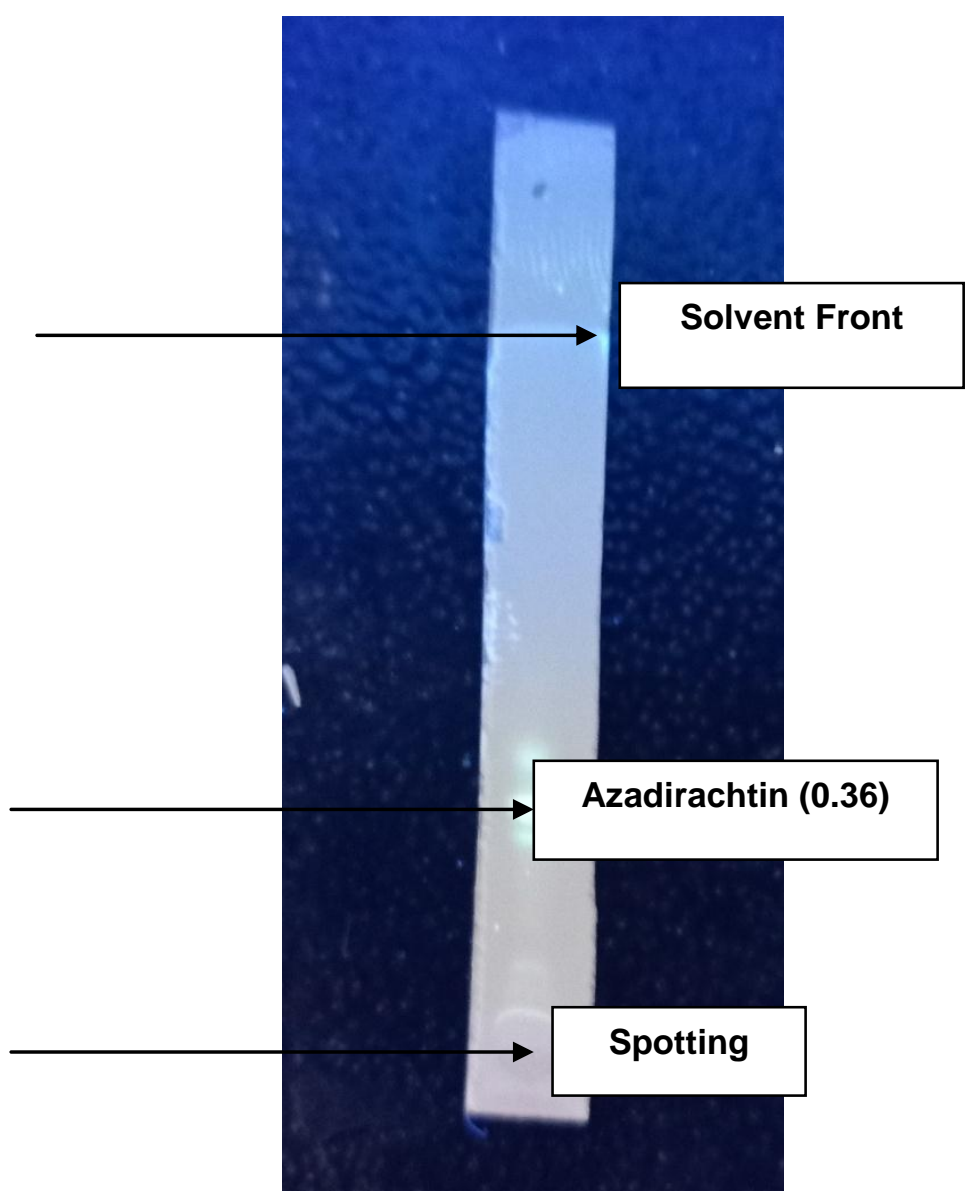

Fig. 1: TLC of Neem Seed Oil

\section{REFERENCES}

1. Khadbadi SS. Pharmacognosy and Phytochemistry: A comprehensive guide. Adityaoffset publications, Hyderabad. 2014.

2. Kokate CK, Gokhale SB and Purohit AP. Pharmacognosy. $55^{\text {th }}$ edition, Nirali Publications, Pune. 2008.

3. Kokate CK. Practical Pharmacognosy. Vallabh Prakashan, Delhi. 2004.

4. Rangari VD. Pharmacognosy \& Phytochemistryvol -1 . Career Publications, Nashik. 2017.

5. Khandelwal KR. Practical pharmacognosy- Techniques and Experiments. Nirali Prakashan, Pune. 2016.

6. Subhash M. Pharmacognostic profiles of AzadirachtaindicaA. Juss Leaves. Ancient science of life. 2000;(3\&4):118-122.
7. Biu AA, Yusufa SD and Rabo JS. Phytochemical screening of Azadirachta indica (Neem) (Meliaceae) in Maiduguri, Nigeria. Bioscience research communications. 2009;21(6):281-283.

8. Khan $\mathrm{M}$ and Ahmad M. Authentication of herbal medicine neem (Azadirachta indica A. Juss.) by using Taxonomic \& Pharmacognostic techniques. Pakistan journal of botany. 2011;43:141-150.

9. Singh S, More PK and Gaikwad K. Standardization of Process Parameters for Neem oil \& Determination of Properties for using as a Fuel. International journal of Engineering Research and General Science. 2014;2(6). 